\title{
Expression and Endocytosis of Lysosomal Aspartylglucosaminidase in Mouse Primary Neurons
}

\author{
Aija Kyttälä, ${ }^{1}$ Outi Heinonen, ${ }^{1}$ Leena Peltonen, ${ }^{1,2}$ and Anu Jalanko ${ }^{1}$ \\ ${ }^{1}$ Department of Human Molecular Genetics, National Public Health Institute, and 2Department of Medical Genetics, \\ University of Helsinki, FIN-00300 Helsinki, Finland
}

\begin{abstract}
Aspartylglucosaminuria (AGU) is a neurodegenerative lysosomal storage disease that is caused by mutations in the gene encoding for a soluble hydrolase, aspartylglucosaminidase (AGA). In this study, we have used our recently developed mouse model for AGU and analyzed processing, intracellular localization, and endocytosis of recombinant AGA in telencephalic AGU mouse neurons in vitro. The processing steps of AGA were found to be similar to the peripheral cells, but both the accumulation of the inactive precursor molecule and delayed lysosomal processing of the enzyme were detected. AGA was distributed to the cell soma and neuronal processes but was not found in the nerve terminals. Endocytotic capability of cultured telencephalic neurons was comparable to that of fibroblasts, and endocytosis of AGA was blocked by free mannose-6-phosphate (M6P), indicating that uptake of the enzyme was mediated by M6P receptors (M6PRs). Uptake of
\end{abstract}

extracellular AGA was also studied in the tumor-derived cell lines rat pheochromocytoma (PC12) and mouse neuroblastoma cells (N18), which both endocytosed AGA poorly as compared with cultured primary neurons. Expression of cationindependent M6PRs (Cl-M6PRs) in different cell lines correlated well with the endocytotic capability of these cells. Although a punctate expression pattern of $\mathrm{Cl}-\mathrm{M} 6 \mathrm{PRs}$ was found in fibroblasts and cultured primary neurons, the expression was beyond the detection limit in PC12 and N18 cells. This indicates that PC12 and N18 are not feasible cell lines to describe neuronal uptake of mannose-6-phosphate-tagged proteins. This in vitro data will form an important basis for the braintargeted therapy of AGU.

Key words: aspartylglucosaminidase; aspartylglucosaminuria; lysosomal enzyme; mannose-6-phosphate receptor; primary neurons; mouse
Aspartylglucosaminuria (AGU) is a lysosomal storage disease resulting from deficiency of the soluble hydrolase aspartylglucosaminidase (AGA), which is required in glycoprotein catabolism in the lysosomes (Pollit et al., 1968). AGU results in the accumulation of uncleaved glycoasparagines, which are stored in large vacuoles in various tissues of AGU patients (Maury, 1979). As the major disease manifestation, AGU patients suffer from progressive and severe dysfunction of the CNS (Autio, 1973; Aula et al., 1982). In the CNS, AGU is primarily a gray matter disease, but it also affects the white matter, most probably by delayed myelination. Magnetic resonance imaging (MRI) studies of the brains of AGU patients show significant differences in signal intensities between the gray and white matter when compared with the healthy controls (Autti et al., 1997). However, neither MRI nor the histopathological analysis have shown significant atrophy in the AGU brains (Haltia et al., 1975; Autti et al., 1997).

Aspartylglucosaminidase is synthesized as an inactive precursor polypeptide, which is activated in the endoplasmic reticulum (ER) by dimerization followed by proteolytic cleavage into $\alpha$ - and $\beta$-subunits (Ikonen et al., 1993; Riikonen et al., 1996). The threedimensional structure of this $\mathrm{N}$-terminal nucleophile hydrolase has been resolved, and consequently the structural determinants

Received April 1, 1998; revised July 20, 1998; accepted July 22, 1998

This work was financially supported by The Academy of Finland, The Sigrid Juselius Foundation, and The Hjelt Fund. We thank Dr. Annette Hille-Rechfeld (Göttingen, Germany) for providing the M6PR 300 antibody.

Correspondence should be addressed to Dr. Anu Jalanko, Department of Human Molecular Genetics, National Public Health Institute, Mannerheimintie 166, FIN00300 Helsinki, Finland.

Copyright (C) 1998 Society for Neuroscience $\quad 0270-6474 / 98 / 187750-07 \$ 05.00 / 0$ affecting the mannose-6-phosphate receptor-mediated lysosomal transport have also been characterized (Oinonen et al., 1995; Tikkanen et al., 1997). The major disease causing mutation is a double point mutation $\mathrm{G} 482 \mathrm{~A}+\mathrm{G} 488 \mathrm{C}$, both resulting in amino acid substitutions in the AGA polypeptide (R161Q and C163S, respectively) (Ikonen et al., 1991a). This mutation is highly enriched in the Finnish population and is alone responsible for $98 \%$ of the AGU alleles (Syvänen et al., 1992). The consequences of different mutations are well characterized, and they mainly influence folding and activation of the nascent AGA precursor and result in a failure of lysosomal transport (Ikonen et al., 1991b; Peltola et al., 1994, 1996; Riikonen et al., 1994, 1996; Jalanko et al., 1995).

AGA is expressed ubiquitously, but both the specific activity (Palo et al., 1972) and the protein level (Enomaa et al., 1993) of the enzyme have been reported to be low in brain as compared with other tissues. Detailed characterization of the expression of AGA in mouse brain during development showed that AGA mRNA levels, which were high during embryogenesis, were decreased at the time of birth and raised again postnatally. Furthermore, Western blot analysis revealed that the processing of the AGA precursor molecule was defective, and only low amounts of active subunits of the enzyme could be detected in mouse brain tissue (A. Uusitalo, K. Tenhunen, O. Heinonen, J. Hiltunen, M. Saarma, M. Haltia, A. Jalanko, and L. Peltonen, unpublished observations).

To further characterize the synthesis and processing of AGA in CNS neurons, we monitored the expression of Semliki Forest virus (SFV)-mediated AGA in primary telencephalic neurons derived from the AGU mouse embryos (Jalanko et al., 1998). 
Furthermore, to evaluate the potential of gene or substitution therapy for CNS neurons of AGU patients, we also studied the capability and mechanism of these cultured neurons to uptake the AGA enzyme from the extracellular milieu.

\section{MATERIALS AND METHODS}

Cell culture. Primary neuronal cell cultures were prepared aseptically from telencephalon of 14- to 16-d-old AGU mouse (Jalanko et al., 1998) embryos. Meningeal membranes were removed in an ice-cold solution of PBS-20 mm glucose, and the brain tissue was gently triturated with a 5 $\mathrm{ml}$ pipette in PBS-20 mM glucose containing trypsin-EDTA $(0.1 / 0.04 \%)$ and DNase I $(10 \mu \mathrm{g} / \mathrm{ml})$. The tissue was then allowed to dissociate at $37^{\circ} \mathrm{C}$ for $15 \mathrm{~min}$. Trypsin was inactivated by $10 \%$ fetal calf serum (FCS) (Life Technologies, Gaithersburg, MD), and the dispersed sample was centrifuged at $800 \mathrm{rpm}$ for $2 \mathrm{~min}$. The cells were resuspended with culture medium CM1 [CM1: DMEM (Life Technologies) supplemented with $25 \mu \mathrm{M}$ L-glutamic acid, $0.5 \mathrm{mM}$ L-glutamine, penicillin/streptomycin $(50 \mathrm{U} / \mathrm{ml} / 50 \mathrm{mg} / \mathrm{ml}), 1 \times \mathrm{B} 27$ (Life Technologies), and $10 \mathrm{~mm}$ HEPES, $\mathrm{pH}$ 7.4,] and two hemispheres were plated on poly-D-lysine-coated $5 \mathrm{~cm}$ Petri dishes (with or without coverslips). After 2-4 d of incubation, the culture medium was replaced with new medium CM2 [CM2: CM1 without L-glutamic acid and supplemented with $5 \mu \mathrm{M}$ antimitotic agent cytosine arabinoside Ara C (Sigma, St. Louis, MO)] and replaced every third day until it was analyzed.

Rat pheochromocytoma cells (PC12 cells, ATCC) were cultured on collagen-coated cell culture dishes in RPMI 1640 medium (Life Technologies) supplemented with 5\% FCS, $10 \%$ horse serum (HS) (Vector Laboratories, Burlingame, CA), $2 \mathrm{~mm}$ L-glutamine, and antibiotics. For differentiation, PC12 cells were cultured in RPMI 1640 with $1 \%$ HS and $50 \mathrm{ng} / \mathrm{ml}$ nerve growth factor (NGF) (Alomone Labs, Jerusalem, Israel).

Both the mouse fibroblasts and the mouse neuroblastoma cell line N18 (NB41A3, CCL 147) were grown on tissue culture dishes (Falcon) in DMEM supplemented with 10\% FCS, 2 mM L-glutamine, and antibiotics. Baby hamster kidney (BHK) cells, BHK21 (CCL10(13), CRL8544, ATCC) were cultured in Glasgow's modified Eagle's medium (Life Technologies) supplemented with 5\% FCS, 2 mM L-glutamine, $10 \%$ tryptosephosphate broth, and penicillin/streptomycin.

Semliki Forest virus infection and metabolic studies. The wild-type (wt) AGA cDNA coding region as well as the mutated $\mathrm{AGU}_{\text {Fin }}$ cDNA containing the most common disease-causing mutation R161Q,C163S (Ikonen et al., 1991a) were cloned to Bam HI site of the pSFV vector, and the recombinant $\mathrm{AGA} / \mathrm{AGU}_{\mathrm{Fin}}-\mathrm{SFVs}$ were prepared as described in detail by Olkkonen et al. (1994). The primary neuronal cells and the BHK cells were incubated with recombinant SFV for $2 \mathrm{hr}$ in $5 \% \mathrm{CO}_{2}$ at $37^{\circ} \mathrm{C}$. After $2 \mathrm{hr}$ infection, the virus was removed, and the incubation was continued in maintenance medium for $3 \mathrm{hr}$ to confirm the extensive synthesis of the AGA polypeptides. The cells were starved in cysteine-

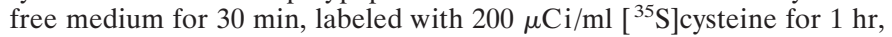
and chased for 1-6 hr in FCS-free DMEM. The cells were harvested and lysed with $100 \mu \mathrm{l}$ of PBS-1\% Triton X-100. Immunoprecipitation of the lysed samples was performed as described by Riikonen et al. (1994). The precipitated proteins were separated by $14 \%$ SDS-PAGE (Laemmli, 1970), and the radioactive bands were visualized by fluorography using Amplify reagent (Amersham, Arlington Heights, IL).

For immunofluorescence analysis, the primary neuronal cells, seeded on poly-D-lysine-coated $12 \mathrm{~mm}$ coverslips, were infected for $2 \mathrm{hr}$ with AGA/AGU $\mathrm{Fin}-\mathrm{SFV}$ and incubated for an additional $4 \mathrm{hr}$ in the maintenance medium. To block the protein synthesis, $100 \mu \mathrm{g} / \mathrm{ml}$ cycloheximide was added to the culture medium of the infected cells, and the incubation was continued for different time periods. The cells were fixed with freshly made $4 \%$ paraformaldehyde for $10 \mathrm{~min}$ at room temperature, washed with PBS, and permeablized in PBS- $0.1 \%$ Triton X-100 for $30 \mathrm{~min}$. After permeablization, the cells were incubated in PBS-0.5\% BSA for $30 \mathrm{~min}$ and for an additional $1 \mathrm{hr}$ at $37^{\circ} \mathrm{C}$ with primary antibodies: rabbit antiserum against AGA (1:200) (Halila et al., 1991) combined with mouse antibody against neurofilament $160 \mathrm{kDa}$ (1:10) (Boehringer Mannheim, Indianapolis, IN) or mouse anti-microtubules-associated protein 1 or 2 (MAP1 and MAP2, both diluted to 1:500; Sigma) or mouse anti-synaptophysin (1:50, Dako, Glostrup, Denmark) or mouse anti-protein disulfide isomerase (PDI) (1:200; StressGen). The cell samples were extensively rinsed with PBS and stained with a 1:150 dilution of fluorescein-conjugated goat anti-mouse $\mathrm{IgG}$ and rhodamineconjugated goat anti-rabbit IgG (Immunotech, Marseille, France) for 30 $\min$ at $37^{\circ} \mathrm{C}$. The coverslips were mounted in Gel Mount (Biomeda) and viewed with a Leica confocal microscope.

Uptake of extracellular AGA. The recombinant Chinese hamster ovary (CHO)-AGA cells (Riikonen et al., 1996) were labeled with [ ${ }^{35}$ S $]$ cysteine for $4 \mathrm{hr}$, followed by incubation for $20 \mathrm{hr}$ in fresh chasing medium. The medium containing the secreted and labeled AGA polypeptides was collected and concentrated by Centricon 10 (Amicon). Total activity of $15 \times 10^{6} \mathrm{cpm}$ of the concentrated media, with or without $5 \mathrm{~mm}$ mannose 6-phosphate (Sigma), was added to the media of the unlabeled cells (primary neurons, fibroblasts, N18, PC12). After incubation for $24 \mathrm{hr}$, the cells were harvested and calculated to equalize the cell number of different samples. The samples were immunoprecipitated and analyzed on $14 \%$ SDS-PAGE as described above. Internalization of the AGA enzyme was detected by monitoring the maturation of the secreted 27 $\mathrm{kDa} \alpha$-subunit into the lysosomal $24 \mathrm{kDa}$ form (Ikonen et al., 1993). To detect endocytosis of the AGA enzyme specifically in neurons, the coverslips were removed from the cell culture dishes before harvesting, and the cells were fixed with $4 \%$ paraformaldehyde for $10 \mathrm{~min}$. The cells were stained for immunofluorescence analysis as described above.

Expression of CI-M6PRs. Mouse fibroblasts, N18 cells, and PC12 cells (without any induction) were cultured for $2 \mathrm{~d}$ before they were analyzed for the expression of CI-M6PRs. Expression of CI-M6PRs was analyzed in the primary neuronal cells 2,8 , and $13 \mathrm{~d}$ after plating. The cells were fixed with $4 \%$ paraformaldehyde and permeabilized with PBS $-0.1 \%$ Triton X-100 for $20 \mathrm{~min}$. The cells were incubated for $1 \mathrm{hr}$ at room temperature with goat anti-human M6PR300 (kindly provided by Dr. Anette Hille-Rehfeld, Geor-August-University, Göttingen, Germany) diluted to $1: 200$, followed by incubation with horse radish peroxidaseconjugated anti-goat IgG (Jackson ImmunoResearch, West Grove, PA) diluted to 1:250. Expression of CI-M6PRs was visualized with $0.05 \%$ $3,3^{\prime}$-diaminobenzidine/ $0.3 \% \mathrm{H}_{2} \mathrm{O}_{2}$ in PBS for $5 \mathrm{~min}$. The cell samples were mounted in Gel Mount (Biomeda), and bright-field images were digitized using an Olympus AX70 Provis microscope (Olympus Optical, Tokyo, Japan) equipped with a Photometrix Sensys CCD camera (Photometrix, Tucson, AZ) and image ProPlus 3.0 software (Media Cybernetics, Silver Spring, MD).

\section{RESULTS}

\section{Expression of wt and mutated AGA in primary neuronal cells}

Recombinant SFV containing AGA cDNA was used as a transport vehicle to study expression of the AGA enzyme in mouse primary neuronal cell cultures. BHK cells were chosen as control cells to represent peripheral processing steps of AGA. Both of the cell lines, the BHK cells and the neuronal cell cultures from telencephalon of 14-d-old mouse embryos, were infected with wt AGA-SFV, and the maturation of the enzyme was monitored by pulse labeling of the expressed polypeptides and by SDS-PAGE analysis. In the BHK cells, the $42 \mathrm{kDa}$ precursor of AGA is cleaved soon after synthesis into the $27 \mathrm{kDa} \alpha$ - and $17 \mathrm{kDa}$ $\beta$-subunits. After $1 \mathrm{hr}$ chase, appearance of the mature, $24 \mathrm{kDa}$ lysosomal form of the $\alpha$-subunit can be detected, and after $6 \mathrm{hr}$ of chase, the $14 \mathrm{kDa} \beta^{\prime}$-subunit, which results from a proteolytic cleavage in the $\mathrm{C}$ terminus of the $\beta$-subunit (Fig. $1 A$ ), can be detected. In the mouse neuronal cell cultures (cultured for $2 \mathrm{~d}$ after plating and containing $>80 \%$ of neurofilament positive cells), the processing steps of AGA followed that detected in the BHK cells (Fig. 1A) and described earlier in several studies using different cell lineages (Enomaa et al., 1992; Ikonen et al., 1993; Riikonen et al., 1994, 1995; Tikkanen et al., 1995). However, maturation of AGA seemed to occur more slowly in the primary neurons when compared with BHK cells. Although the amount of the recombinant AGA polypeptides was low in the samples immunoprecipitated from neuronal cells, the relative amount of the precursor molecule (compared with the amount of the active subunits) seemed to remain high during chasing. Because the endogenous precursor molecule could not be immunoprecipitated from the noninfected AGU neurons (data not shown), all of the 

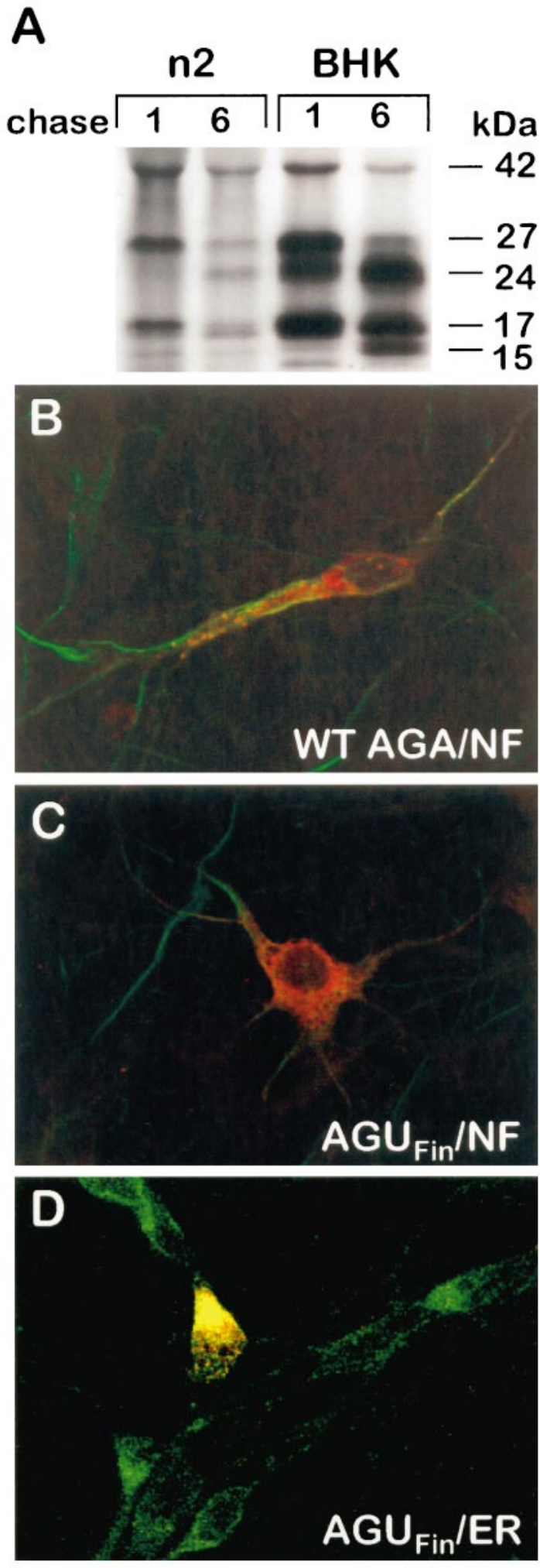

Figure 1. Semliki Forest virus-mediated expression of AGA in primary neurons. $A$, Primary neurons from E14 AGU mouse embryos, cultured for $2 \mathrm{~d}(n 2)$, and BHK cells were infected with SFV-AGA and pulse-labeled for $1 \mathrm{hr}$ with $\left[{ }^{35} \mathrm{~S}\right]$ cysteine $3 \mathrm{hr}$ after infection. The cells were chased for 1 and $6 \mathrm{hr}$, after which AGA was immunoprecipitated by polyclonal AGA antibody and separated on SDS-PAGE. The $42 \mathrm{kDa}$ AGA precursor and the 27 and $24 \mathrm{kDa} \alpha$ - and $17 \mathrm{kDa}$ and $14 \mathrm{kDa} \beta$-subunits are indicated. $B$, Immunofluorescence staining of SFV-mediated AGA (red) and neurofilament (green) with confocal microscopy. E14 AGU mouse neurons were detected precursors originated from the recombinant AGA enzyme. Furthermore, although the mature $24 \mathrm{kDa} \alpha$-subunit is found to be the major subunit after chasing for $6 \mathrm{hr}$ in BHK cells, only half of the $\alpha$-subunits were found in this mature lysosomal form in the neuronal cell cultures (Fig. 1A).

Immunofluorescence analysis was used to study the intracellular localization of AGA. The cultured neurons were infected with the wt AGA-SFV for $2 \mathrm{hr}$, and $4 \mathrm{hr}$ after infection the synthesis of the expressed proteins was stopped by adding cycloheximide. Incubation was continued further for different time periods to allow the expressed polypeptides to be transported to their final destination. Neuron-specific expression of AGA was detected by double labeling with mouse antibody against $160 \mathrm{kDa}$ neurofilament polypeptide and rabbit antiserum raised against AGA (Halila et al., 1991). Analysis of the neurofilament-positive cells showed that the AGA enzyme was distributed to the cell soma and neuronal processes (Fig. $1 B$ ). The staining pattern of AGA colocalized to some extent with both MAP1 and MAP2, but no difference was detected in the distribution of AGA between axons and dendrites. Also, no colocalization of AGA with the staining of synaptophysin could be detected, indicating that AGA is not transported to the nerve terminals (data not shown). However, when the expression pattern of AGA was monitored at the different chase periods, the complete lysosomal-like staining pattern appeared as late as $10 \mathrm{hr}$ after the protein synthesis had been stopped. This was distinctly longer than the time detected in BHK cells (data not shown). Thus the microscopic examination was in agreement with the data from the pulse-chase analysis, revealing a delay in the intracellular transport of AGA in cultured primary neurons.

The telencephalic cell cultures were also infected with $\mathrm{AGU}_{\mathrm{Fin}^{-}}$ SFV containing the most common AGU disease-causing mutation (R161Q, C163S) (Ikonen et al., 1991a). This mutation has been shown to block the processing and activation of the AGA precursor, resulting in prevented transport of the mutated AGA polypeptides out from the ER (Ikonen et al., 1991b; Riikonen et al., 1994). The expression of the mutated AGA showed that also in the primary neurons the polypeptides were arrested in the cell soma and the lysosomal-like staining pattern was missing (Fig. $1 C)$. The $\mathrm{AGU}_{\text {Fin }}$ polypeptide was colocalized with the endoplasmic reticulum-specific marker PDI, which was visualized by a monoclonal antibody (Fig. 1D).

\section{Uptake of recombinant AGA into neuronal cell lines}

To study neuronal uptake of the AGA enzyme, the recombinant CHO-AGA cell line (Riikonen et al., 1996) was labeled with $\left[{ }^{35} \mathrm{~S}\right]$ cysteine, and the media containing the secreted and labeled AGA was used to feed different neuronal cell lines. Internalization of AGA was monitored on SDS-PAGE by appearance of the $24 \mathrm{kDa}$ lysosomal form of the $\alpha$-subunit.

The neuronal cell cultures from the 14-d-old embryos of AGU mice were fed with labeled AGA for $24 \mathrm{hr}$ after culturing the cells for 2 and $16 \mathrm{~d}$ of plating. Somewhat surprisingly, the amount of

fixed 14 hr after SFV-AGA infection and stained with polyclonal AGA antibody and monoclonal neurofilament antibody. Secondary antibodies were anti-rabbit-TRITC and anti-mouse-FITC, respectively. $C$, Same as $B$ except that the cells were infected with the mutant SFV-AGU $\mathrm{Fin}_{\text {. }} D$, E14 AGU mouse neurons infected with SFV-AGU Fin $_{\text {and immunostained }}$ with the polyclonal AGA antibody (red) and monoclonal PDI antibody (green). Colocalization of the stainings is seen as yellow. Magnification $600 \times$. 


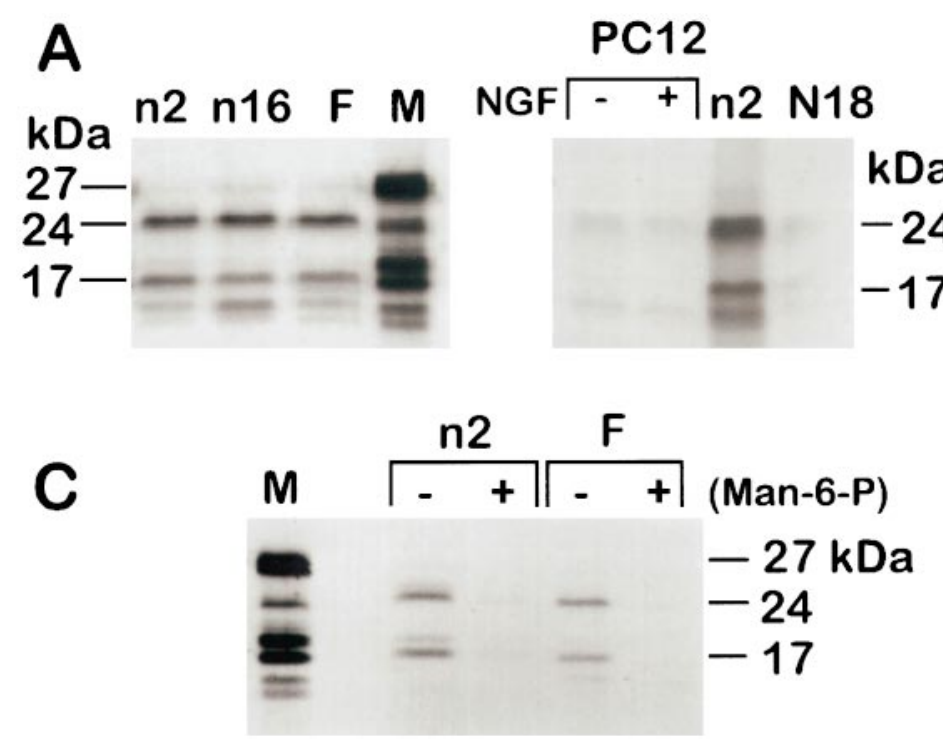

\section{B}

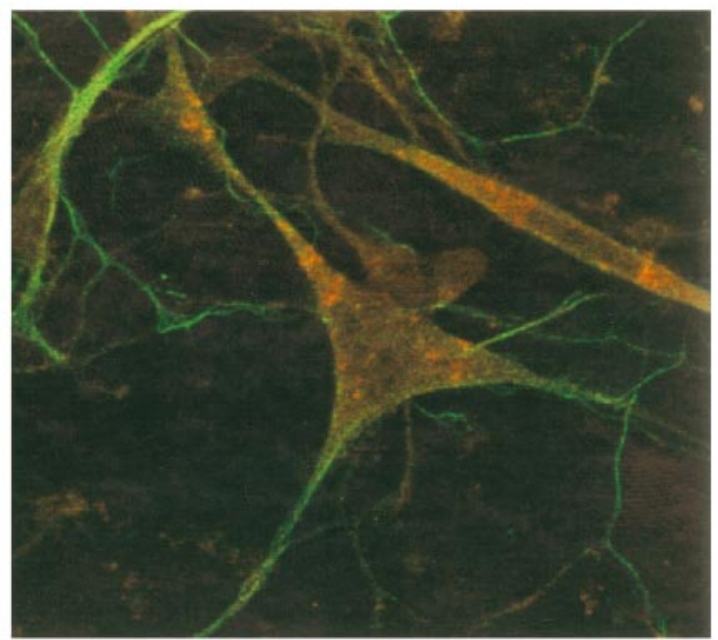

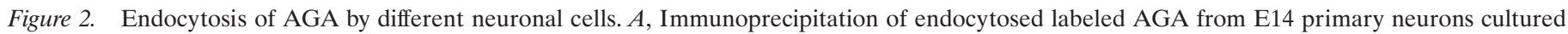

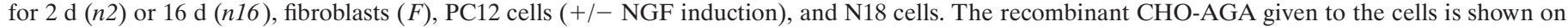

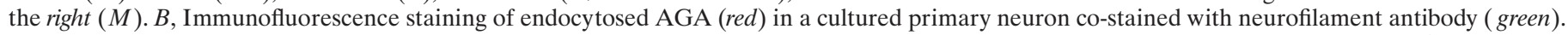

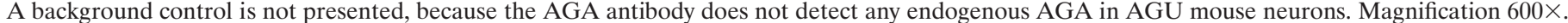

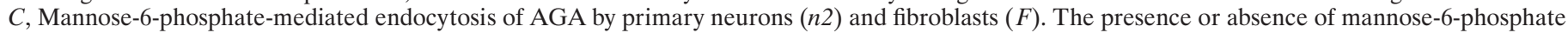
is indicated $(+/-)$.

the endocytosed AGA remained stable during $16 \mathrm{~d}$ of culturing and was comparable to uptake detected in the mouse fibroblasts (Fig. 2A). Neuron-specific internalization of AGA was again verified by immunofluorescence analysis of the neurofilamentpositive cells (Fig. 2B).

Uptake of recombinant AGA was also tested in rat pheochromocytoma cell line PC12, which can be differentiated into cells resembling sympathetic neurons in the presence of NGF (Greene and Tischler, 1976). Both the nondifferentiated and NGF-induced PC12 cells seemed to endocytose equally the extracellular AGA, but the amount of the internalized enzyme was very low compared with that observed in primary neurons (Fig. 2A). A similar finding was established with the nondifferentiated mouse neuroblastoma cell line N18 (Amano et al., 1972), in which the amount of the endocytosed AGA was barely detectable when monitored on SDS-PAGE (Fig. 2A).

We also wanted to study to what extent the uptake of AGA in the primary neuronal cells was mediated by the M6PRs. Primary neurons cultured for $2 \mathrm{~d}$ and mouse fibroblasts were fed with media containing the recombinant AGA in the presence of $5 \mathrm{~mm}$ mannose-6-phosphate. Addition of free M6P totally blocked internalization of the recombinant AGA enzyme (Fig. 2C), indicating that the endocytosis mainly occurred via M6PRs in both cell lines.

\section{Expression of M6PR}

Because all of the experiments determined that the uptake of AGA occurs in an M6P manner, the expression of CI-M6PRs was studied in different neuronal cell cultures. Mouse fibroblasts were selected to represent peripheral expression patterns of the intracellular CI-M6PRs. In these control fibroblasts, punctate expression patterns of CI-M6PRs was detected around the nucleus and at the perikaryal area (Fig. $3 A$ ). A similar expression pattern was found in the mouse primary neuronal cells cultured for $2 \mathrm{~d}$ after plating (Fig. 3B). The amount of the immunopositive granules seemed to remain stable during culturing of the primary neurons for 8 or even $13 \mathrm{~d}$ (Fig. $3 C, D$ ). Contrary to these results, no detectable immunoreactivity for CI-M6PRs was monitored in PC12 or N18 cells (Fig. 3E,F).

\section{DISCUSSION}

The high expression capacity and efficient infection of neurons by Semliki Forest virus vector was used to show the processing and localization of AGA in the cultured telencephalic neurons derived from the AGU mouse (Jalanko et al., 1998) embryos. Both pulse-chase analyses and immunofluorescence detection of the expressed AGA polypeptides showed that the ER cleavage of the inactive precursor molecule and the lysosomal processing of the AGA enzyme were delayed in cultured primary neurons as compared with BHK cells. The processing of AGA is known to be sensitive for some overexpression systems (Riikonen et al., 1995), but here the detected delay in the neuronal maturation of AGA hardly resulted from SFV-mediated expression, because the processing of the SFV-expressed AGA occurred without any delay in the BHK cells. Furthermore, our finding is consistent with the data from the tissue analysis of the expression of AGA in the mouse brain during development, in which the delayed processing of the AGA precursor molecule and correspondingly low amounts of the active subunits of the enzyme were discovered (Uusitalo, Tenhunen, Heinonen, Hiltunen, Saarma, Haltia, Jalanko, and Peltonen, unpublished results). Whether the observed delayed processing of AGA in the neural cells has any biological significance still needs to be determined.

AGA immunoreactivity has been shown previously in immunohistochemical analyses in the soma of pyramidal (Enomaa et al., 1993) and Purkinje cells (Uusitalo, Tenhunen, Heinonen, Hiltunen, Saarma, Haltia, Jalanko, Peltonen, unpublished observations). Furthermore, AGA staining has been found in the perikaryon and the apical dendrites of the neurons of cerebral cortex (Uusitalo, Tenhunen, Heinonen, Hiltunen, Saarma, Haltia, Jalanko, and Peltonen, unpublished observations). Here we show 

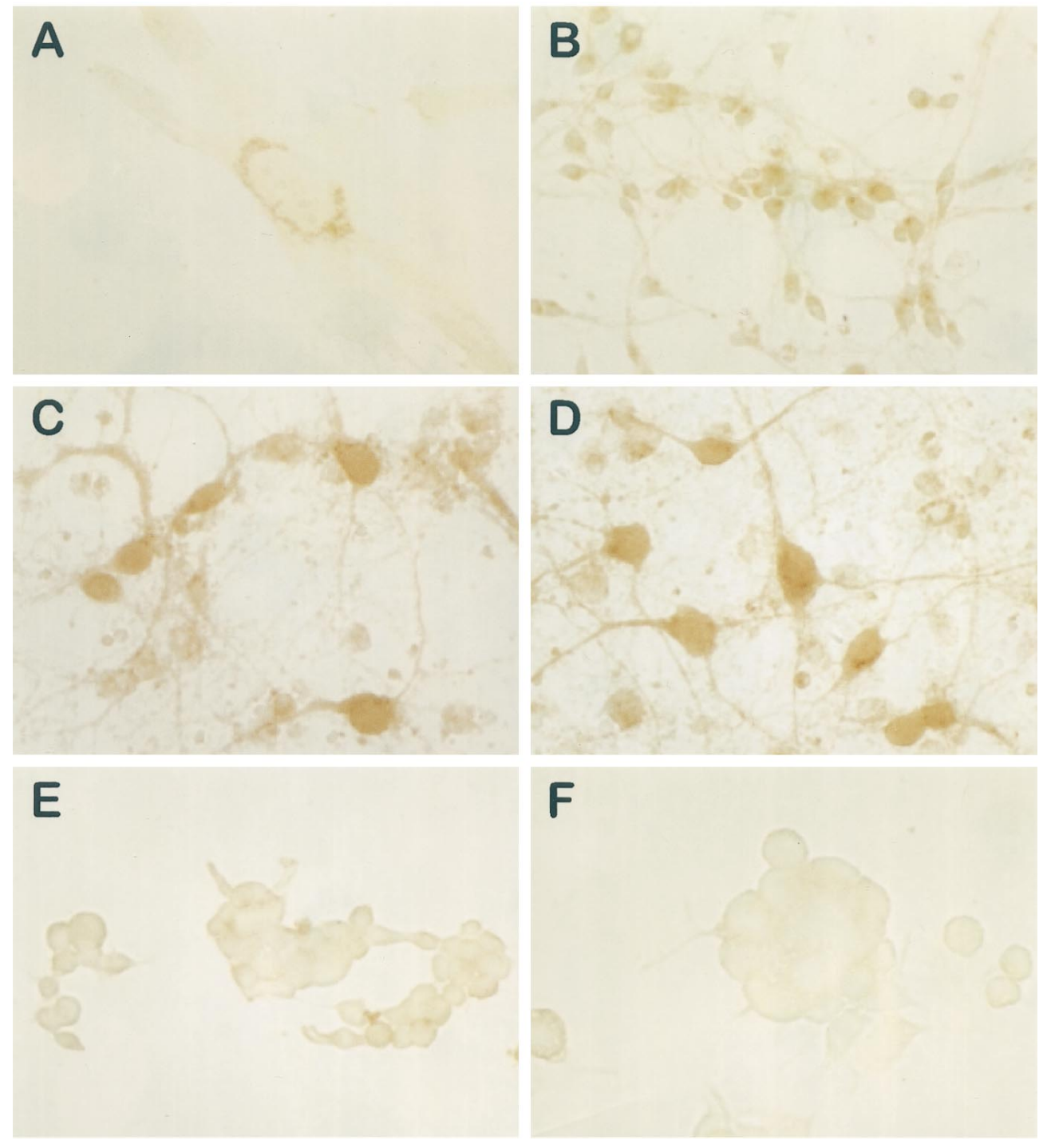

Figure 3. Expression of CI-M6PR in neuronal cells. CI-M6PR was analyzed from mouse fibroblasts $(A)$ and cultured primary neurons $2(B), 8(C)$, and $13(D)$ $\mathrm{d}$ after plating. CI-M6PR was immunostained with goat anti-human M6PR 300 followed by HRP-conjugated anti-goat IgG. M6PR immunostaining was also performed in PC12 cells $(E)$ and N18 cells $(F)$.

that the expressed AGA polypeptides were distributed in the lysosomal-like granules throughout the cytoplasm of the telencephalic neurons. The intracellular localization of AGA did not show notable axonal-dendritic specificity, and AGA immunoreactivity was not significantly found in the nerve terminals. Contrary to the wild-type enzyme, the mutated AGU polypeptides (carrying the most common AGU disease-causing mutation) were found only in the neuronal cell soma.

We showed earlier that AGA is transported to the lysosomes via M6PR- mediated pathways (Tikkanen et al., 1995). Furthermore, the recognition signals of phosphotransferase have been characterized from the three-dimensional structure of AGA (Tikkanen et al., 1997). We have also shown in vitro that AGA migrates from cell to cell by receptor-mediated endocytosis and that neuroblastoma cell line N18 can take up AGA from the extracellular media, but not as effectively as human fibroblasts (Enomaa et al., 1995). Here we demonstrate that internalization of extracellular AGA occurs by an M6P-dependent manner also in cultured primary neurons, because free M6P could totally block the endocytosis of AGA in these cells. The amount of the endocytosed enzyme in primary neurons was comparable to that detected in cultured mouse fibroblasts and remained stable during culturing for $>2$ weeks, at which time the maturation of neural cells was evident. Contrary to these findings, the tumorderived neural cell lines PC12 and N18 indicated a much lower capability to endocytose AGA from the extracellular media than cultured primary neurons.

Internalization of the AGA enzyme in the analyzed cell lines correlated well with the expression pattern of CI-M6PRs in these cells. Although the PC12 and N18 cells did not display any detectable immunoreactivity for CI-M6PRs, the expression pattern was punctate and remained constant in telencephalic neurons during culturing. Expression of CI-M6PRs in the CNS of different animal models has been reported previously in several studies (Van Schravendijk et al., 1986; Lesniak et al., 1988; Ocrant et al., 1988; Nielsen et al., 1991). The CI-M6PR is identical to insulin growth factor II (IGF II) receptor (Morgan et al., 1987; Kiess et al., 1988), and most of the reported data are based on the affinity-labeling studies describing the binding of IGF II to its receptor. IGF II is known to mediate its biological effect through the IGF I receptor, whereas the CI-M6P/IGF II receptor mediates internalization and degradation of IGF II. Therefore the affinity-labeling methods may not always be feasible in examining directly the expression of these receptors. Somewhat contradictory results have been reported of the expression of CI-M6P/IGF II receptors in fetal and adult brain cells. Although most of the 
data agree that cultured fetal neurons from rat or murine origin express CI-M6PRs (Van Schravendijk et al., 1986; Ocrant et al., 1988; Nielsen et al., 1991; Stewart et al., 1997), in some of the studies the amount of the receptors decreased in the adult brain tissue (Ocrant et al., 1988) or during maturation of neural cells in the culture (Stewart et al., 1997). Our data suggest that the amount of CI-M6PRs in cultured murine telencephalic neurons and, correspondingly, the rate of the endocytosis of proteins tagged with M6P signals remain constant during neuronal maturation in vitro. Discrepancy between different studies may result from regional differences in the brains or analyzed cell types. Furthermore, primary cell cultures always contain a heterogenic population of neuronal and glial precursor cells and therefore may show variations in each culture. In addition, in vitro properties of different cells may not always correlate in vivo, where the cells grow in their natural environment. However, our finding that tumor-derived cell lines PC12 and N18 express only minimal amounts of CI-M6PRs, which was seen as a poor endocytosis of extracellular AGA, suggests that although these cell lines are widely used as a model for neuronal differentiation, they may not be ideal to monitor the capability of neuronal cells to endocytose M6P-tagged proteins.

When planning different CNS-targeted therapy for AGU, detailed analyses of expression and cellular routing of AGA in CNS cells are needed. The most probable future treatments for AGU rely on BMT or gene therapy or the combination of these two approaches. Several studies have suggested that bone marrow transplantation may be a feasible treatment for diseases with neuronal degeneration when accomplished in the early developmental stage (Ferrara et al., 1992; Sands et al., 1993; Walkley et al., 1994). Early BMT has been reported to give rise in new, donor-derived microglia containing the therapeutic gene (Krall et al., 1994; Kennedy and Abkowitz, 1997). If neurons would maintain their capability to endocytose external enzymes during maturation, as suggested by our in vitro study, the new microglia population derived from BMT might produce sufficient amounts of enzyme to increase the enzyme activity of neurons to the level that exceeds the critical threshold and inhibits the formation of the damaging storage material in neurons. Recent in vivo gene therapy studies with the mouse model of AGU demonstrate that the AGA enzyme actually migrates from cell to cell also in the CNS tissue, which indicates that expression of AGA by a rather small population of neuronal cells may be sufficient to correct the CNS pathology (Peltola, et al., 1998). Although detailed in vivo studies will finally give answers to these important questions, continuous in vitro studies of the proteins in the most vulnerable cell types are required to provide a solid basis for developing therapeutic approaches for neurodegenerative disorders.

\section{REFERENCES}

Amano T, Richelson E, Niremberg M (1972) Neurotransmitter synthesis by neuroblastoma clones. Proc Natl Acad Sci USA 69:258-263.

Aula P, Autio S, Raivio K, Rapola J (1982) Aspartylglucosaminuria. In: Genetic errors of glycoprotein metabolism, pp 123-152. Berlin: Springer.

Autio S, Visakorpi J, Järvinen H (1973) Aspartylglucosaminuria (AGU). Further aspects on its clinical picture, mode of inheritance and epidemiology based on a series of 57 patients. Ann Clin Res 5:149-155.

Autti T, Raininko R, Haltia M, Lauronen L, Vanhanen SL, Salonen O, Aronen HJ, Wirtavuori K, Santavuori P (1997) Aspartylglucosaminuria: Radiologic course of the disease with histopathologic correlation. J Child Neurol 12:369-375.

Enomaa N, Heiskanen T, Halila R, Sormunen R, Seppälä R, Vihinen M, Peltonen L (1992) Human aspartylglucosaminidase. A biochemical and immunocytochemical characterization of the enzyme in normal and aspartylglucosaminuria fibroblasts. Biochem J 286:613-618.

Enomaa N, Lukinmaa P-L, Ikonen E, Waltimo J, Palotie A, Paetau A, Peltonen L (1993) Expression of aspartylglucosaminidase in human tissues from normal individuals and aspartylglucosaminuria patients. J Histochem Cytochem 41:981-989.

Enomaa N, Danos O, Peltonen L, Jalanko A (1995) Correction of deficient enzyme activity in a lysosomal storage disease, aspartylglucosaminuria, by enzyme replacement and retroviral gene transfer. Hum Gene Ther 6:723-731.

Ferrara M, Taylor R, Steward G (1992) Age at marrow transplantation is critical for successful treatment of canine fucosidosis. Transplant Proc 24:2282-2283.

Greene L, Tischler A (1976) Establishment of a noradrenergic clonal line of rat adrenal pheochromocytoma cells which respond to nerve growth factor. Proc Natl Acad Sci USA 73:2424-2428.

Halila R, Baumann M, Ikonen E, Enomaa N, Peltonen L (1991) Human leukocyte aspartylglucosaminidase. Evidence for two different subunits in a more complex native structure. Biochem J 276:251-256.

Haltia M, Palo J, Autio S (1975) Aspartylglucosaminuria: a generalized storage disease; morphological and histochemical studies. Acta Neuropathol 31:243-255.

Ikonen E, Baumann M, Grön K, Syvänen A-C, Enomaa N, Halila R, Aula P, Peltonen L (1991a) Aspartylglucosaminuria: cDNA encoding human aspartylglucosaminidase and the missense mutation causing the disease. EMBO J 10:51-58.

Ikonen E, Enomaa N, Ulmanen I, Peltonen L (1991b) In vitro mutagenesis helps to unravel the biological consequences of aspartylglucosaminuria mutation. Genomics 11:206-211.

Ikonen E, Julkunen I, Tollersrud O-K, Kalkkinen N, Peltonen L (1993) Lysosomal aspartylglucosaminidase is processed to the active subunit complex in the endoplasmic reticulum. EMBO J 12:295-302.

Jalanko A, Manninen T, Peltonen L (1995) Deletion of the C-terminal end of aspartylglucosaminidase resulting in a lysosomal accumulation disease: evidence for a unique genomic rearrangement. Hum Mol Genet 4:435-441.

Jalanko A, Tenhunen K, McKinney CK, LaMarca ME, Rapola J, Autti T, Joensuu R, Manninen T, Sipilä I, Ikonen S, Riekkinen Jr P, Ginns EI, Peltonen L (1998) Mice with aspartylglucosaminuria mutation similar to humans replicate the pathophysiology in patients. Hum Mol Genet 7:265-272.

Kennedy D, Abkowitz J (1997) Kinetics of central nervous system microglial and macrophage engraftment: analysis using a transgenic bone marrow transplantation model. Blood 90:986-993.

Kiess W, Blickenstaff G, Sklar M, Thomas S, Nissley P, Sahagian G (1988) Biochemical evidence that the type II insulin-like growth factor receptor is identical to the cation-independent mannose-6-phosphate receptor. J Biol Chem 263:9339-9344.

Krall W, Challita P, Perlmutter L, Skelton D, Kohn D (1994) Cells expressing human glucocerebrosidase from a retroviral vector repopulate macrophages and central nervous system microglia after murine bone marrow transplantation. Blood 83:2737-2748.

Laemmli U (1970) Cleavage of structural proteins during the assembly of the head of bacteriophage T4. Nature 227:680-685.

Lesniak M, Hill J, Kiess W, Rojeski M, Pert C, Roth J (1988) Receptors for insulin-like growth factors I and II: autoradiographic localization in rat brain and comparison to receptors for insulin. Endocrinology 123:2089-2099.

Maury P (1979) Accumulation of two glycoasparagines in the liver in aspartylglucosaminuria. J Biol Chem 254:1513-1515.

Morgan D, Edman J, Standring D, Fried V, Smith M, Roth R, Rutter W (1987) Insulin-like growth factor II receptor as a multifunctional binding protein. Nature 329:301-307.

Nielsen F, Wang E, Gammeltoft S (1991) Receptor binding, endocytosis, and mitogenesis of insulin-like growth factors I and II in fetal rat brain neurons. J Neurochem 56:12-21.

Ocrant I, Valentino K, Eng L, Hintz R, Wilson D, Rosenfeld R (1988) Structural and immunohistochemical characterization of insulin-like growth factor I and II receptors in the murine central nervous system. Endocrinology 123:1023-1034.

Oinonen C, Tikkanen R, Rouvinen J, Peltonen L (1995) Threedimensional structure of human lysosomal aspartylglucosaminidase. Nat Struct Biol 2:1102-1108.

Olkkonen VM, Dupree P, Simons K, Liljeström P, Garoff H (1994) 
Expression of exogenous proteins in mammalian cells with the Semliki Forest Virus vector. Methods Cell Biol.43:43-53.

Palo J, Riekkinen P, Arstila A, Autio S, Kivimäki T (1972) Aspartylglucosaminuria. Biochemical studies on brain, liver, kidney and spleen. Acta Neuropathol 20:217-224.

Peltola M, Chiatayat D, Peltonen L, Jalanko A (1994) Characterization of a point mutation in aspartylglucosaminidase gene: evidence for a readthrough of a translational stop codon. Hum Mol Genet 3:2237-2242.

Peltola M, Tikkanen R, Peltonen L, Jalanko A (1996) Ser72Pro activesite disease mutation in human lysosomal aspartylglucosaminidase: abnormal intracellular processing and evidence for extracellular activation. Hum Mol Genet 5:737-743.

Peltola M, Kyttälä A, Heinonen O, Rapola J, Paunio T, Revah F, Peltonen L, Jalanko A (1998) Adenovirus-mediated gene transfer results in decreased lysosomal storage in brain and total correction in liver of aspartylglucosaminuria mouse. Gene Ther, in press.

Pollitt R, Jenner F, Merskey Y (1968) Aspartylglucosaminuria. An inborn error of metabolism associated with mental defect. Lancet 2:253-255.

Riikonen A, Ikonen E, Sormunen R, Lehto V-P, Peltonen L, Jalanko A (1994) Dissection of molecular consequences of a double mutation causing a lysosomal disease. DNA Cell Biol 13:257-264.

Riikonen A, Tikkanen R, Jalanko A, Peltonen L (1995) Immediate interaction between the nascent subunits and two conserved amino acids $\operatorname{Trp}^{34}$ and $\mathrm{Thr}^{206}$ are needed for the catalytic activity of aspartylglucosaminidase. J Biol Chem 270:4903-4907.

Riikonen A, Rouvinen J, Tikkanen R, Julkunen I, Peltonen L, Jalanko A (1996) Primary folding of aspartylglucosaminidase: significance of di- sulfide bridges and evidence of early multimerization. J Biol Chem 271:21340-21344.

Sands M, Barker J, Vogler C, Levy B, Gwynn B, Galvin N, Sly W, Birkenmeier E (1993) Treatment of murine mucopolysaccharidosis type VII by syngeneic bone marrow transplantation in neonates. Lab Invest 68:676-686.

Stewart K, Brown O, Morelli A, Fairbairn L, Lashford L, Cooper A, Hatton C, Dexter T, Castro M, Lowenstein P (1997) Uptake of $\alpha$-(L)iduronidase produced by retrovirally transduced fibroblasts into neuronal and glial cells in vitro. Gene Ther 4:63-75.

Syvänen A-C, Ikonen E, Manninen T, Bengtström M, Söderlund H, Aula P, Peltonen L (1992) Convenient and quantitative determination of the frequency of a mutant allele using solid-phase minisequencing: application to aspartylglucosaminuria in Finland. Genomics 12:590-595.

Tikkanen R, Enomaa N, Riikonen A, Ikonen E, Peltonen L (1995) Intracellular sorting of aspartylglucosaminidase: the role of $\mathrm{N}$-linked oligosaccharides and evidence of Man-6-P-independent lysosomal targeting. DNA Cell Biol 14:305-312.

Tikkanen R, Peltola M, Oinonen C, Rouvinen J, Peltonen L (1997) Several co-operating binding sites mediate the interaction of a lysosomal enzyme with phosphotransferase. EMBO J 16:6684-6693.

Van Schravendijk C, Hooghe-Peters E, Van den Brande J, Pipeleers D (1986) Receptors for insulin-like growth factors and insulin on murine fetal cortical brain cells. Biochem Biophys Res Commun 135:228-238.

Walkley S, Thrall M, Dobrenis K, Huang M, March P, Siegel D, Wurzelman S (1994) Bone marrow transplantation corrects the enzyme defect in neurons of the central nervous system in a lysosomal storage disease. Proc Natl Acad Sci USA 91:2970-2974. 